\section{Выводы}

Исследование динамики снежного покрова и промерзания почвы по ряду наблюдений, проведенных на метеорологической площадке ст. Саратов ЮВ, свидетельствует, что с 1975 по 2005 г. произошло заметное сокращение как среднемесячных, так и экстремальных годовых отметок высоты снежного покрова. За последнее 30-летие самый первый, а также устойчивый снежный покров в среднем стали устанавливаться на 3-5 дней позже, чем в период с 1891 по 1980 год. Начало уменьшения снежного покрова стало происходить на 18 дней раньше, а полный сход снега - на 2 дня раньше, вследствие чего установилась тенденция уменьшения продолжительности залегания снежного покрова.

Исследование динамики промерзания почвы на метеорологической станции Саратов ЮВ в период с 1981 по 2003 г. показало, что глубина промерзания и продолжительность морозного периода в почве уменьшается.

Выявленные тенденции связаны с глобальным потеплением климата [3] и напрямую с повышением температуры воздуха в зимний период [4] в Саратове, которое особенно активно стало проявляться в 90-е годы. Повышение температуры воздуха, как минимальной, так и максимальной, особенно существенное за последнее 10-летие $[5,6]$, привело к общей тенденции уменьшения высоты снежного покрова, к сокращению срока его залегания, а также к уменьшению продолжительности промерзания почвы.

Приведенные в работе характеристики и тенденции их изменений следует учитывать при проектировании адаптивно-ландшафтных систем земледелия и разработке технологий возделывания озимых культур. Кроме того, полученные результаты могут быть использованы для метеорологического обеспечения строительной индустрии (укладки фундаментов, прокладки водопроводов и др. коммуникаций).

\section{Библиографический список}

1. Научно-прикладной справочник по климату СССР. Ч. 1-6, вып. 12. Л., 1988. 647 с. (Сер. 3. Многолетние данные).

2. Гмурман B.E. Теория вероятностей и математическая статистика. М., 2003. 479 с.

3. Kukla G., Karl T.R. Nighttime warming and the greenhouse enffect // Environ. Sci. Technol. 1993. Vol. 27, № 8. P. 1468-1474.

4. Скляров Ю.А., Иванова Г.Ф. Проблема глобального и регионального изменения климата // Изв. Сарат. ун-та. Новая серия. 2002. Т. 2, вып. 2. С. 44-48.

5. Левицкая Н.Г., Шаталова О.В. Современные тенденции изменения климата и их влияние на продуктивность сельскохозяйственных культур в Нижнем Поволжье // Проблемы и пути преодоления засухи в Поволжье: В 2 ч. Саратов, 2000. Ч. 2. С. 33-47.

6. Левиикая Н.Г., Шаталова О.В., Иванова Г.Ф. Оценка современных тенденций изменения климата и их последствий для сельскохозяйственного производства в Нижнем Поволжье // Повышение эффективности использования агробиоклиматического потенциала юго-восточной зоны России / ГНУ НИИСХ Юго-Востока Россельхозакадемии. Саратов, 2005. С. 273-284.

\title{
ОПЫТ ЭСТЕТИЧЕСКОЙ ОЦЕНКИ ПРИВЛЕКАТЕЛЬНОСТИ РЕЛЬЕФА САРАТОВА
}

\section{В.В. Копнина}

Саратовский государственный университет, кафедра геоморфологии и геоэкологии E-mail: kopnina@sgu.ru

В статье рассматриваются проблемы имеющихся методик по оценке эстетичности ландшафтов. Приведен опыт по оценке эстетической привлекательности рельефа на примере Саратова. Основами для оценки послужили понятия «морфологический ландшафт» и «морфологический пейзаж».

\section{Experience of an Aesthetic Estimation of Saratov's Relief Allure \\ V.V.Kopnina}

This article is devoted to problems of modern techniques of aesthetic landscapes objective appraisal. Such experience is shown according to example of Saratov. The base for an estimation are concepts «a morphological landscape» and «a morphological scenery».

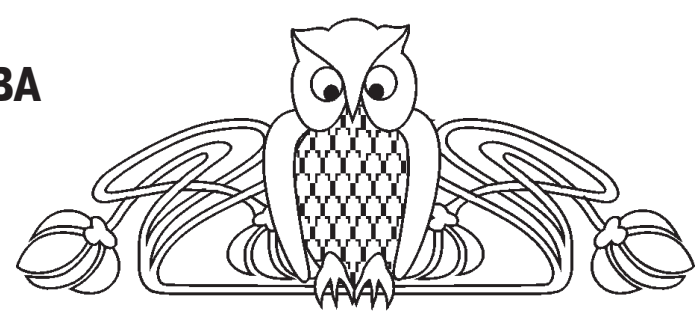

В формировании архитектурно-художественного облика города необходимо выявить природное своеобразие местности, остающееся, несмотря на возможные преобразования городских компонентов ландшафта.

В тех городах, где первоначальная подоснова отличалась выразительным рельефом, развитой гидрографической сетью или ценными насаждениями, эти черты сохраняются на века.

Рельеф земной поверхности является основной составляющей ландшафта. Вопросы эстетической оценки ландшафтов рассматриваются с разных позиций и имеют довольно много разработок в отечественной и зарубежной литературе. 
Эстетическое восприятие ландшафта ассоциируется главным образом с внешним обликом ландшафта - пейзажем. «Пейзаж» - слово французское, обозначает некую местность, точнее ее вид. «Пейзаж» с позиций российской географической школы трактуется как субъект-объектное понятие, обозначающее внешний облик ландшафта, воспринимаемый визуально с той или иной видовой точки либо по ходу маршрута.

Для определения эстетической привлекательности рельефа до сих пор не существует единой методики. Анализ представленных в литературе методик позволяет выделить два подхода к решению проблемы [1]: 1) методики, предполагающие оценку одного из компонентов природного комплекса как основного выражения физиономичности ландшафта (в большинстве случаев это растительность); 2) комплексные системы оценки эстетичности природно-территориального комплекса. Эти методики предполагают покомпонентный анализ эстетических свойств пейзажа (ландшафта) по нескольким параметрам и особенностям сочетания компонентов.

Практически все авторы отмечают территориальную или ландшафтно-типологическую ограниченность применения своих систем оценки. Трудности разработки унифицированной методической базы обусловлены чрезвычайным разнообразием природных ландшафтов, многообразием конкретных целей оценки, разностью экспертных определений, учетом мнения некомпетентных респондентов и пр. Требования практики на современном этапе заставляют уйти от конкретизации и детализации целей эстетической оценки. Необходимо оценить эстетичность природных комплексов в целом, и уже на основе результатов обсуждать виды природопользования той либо иной территории. Пейзаж можно рассматривать как физиономическое выражение ландшафта (природно-территориального комплекса). Именно эта категория является объектом исследования при природно-эстетическом анализе. В данном случае пейзаж отражает не только структурную целостность, но и художественно-образную завершенность природного комплекса, насыщает его дополнительной смысловой и информационной нагрузкой.

Основные свойства пейзажа зависят от сочетания ограниченного набора компонентов ландшафта (рельефа, растительности и водных объектов). Но в данном случае речь идет не о компонентах геосистемы в общих формах, а об их конкретных свойствах, обусловливающих степень эстетичности. Проявление этих сочетаний определяется закономерностями ландшафтной оболочки в целом. Для дифференциации данных проявлений можно использовать оправданные ландшафтоведческие подходы - типологический или территориальный. Однако, учитывая специфику объекта и предмета исследования, наиболее рационально все пейзажное разнообразие рассматривать в рамках основных морфогенетических типов: пейзажей равнин, горных пейзажей и пейзажей побережий. Именно в пределах этих групп можно дать адекватную оценку эстетичности пейзажей и осуществить их сравнение. Эстетические характеристики сравнимы лишь для ландшафтов одного ранга.

По А.В.Бредихину, при решении этих проблем возможно использование двух базисных понятий: «морфологический ландшафт» и «морфологический пейзаж» [2].

Первое понятие, представляющее сущность устройства земной поверхности значительных территорий, - закономерное сочетание генетически связанных форм земной поверхности, свойственных определенному типу природной среды. В качестве основных классификационных признаков следует взять существенные, базисные свойства морфологических ландшафтов, которые определяют разнообразие рельефа: 1) территориальное положение, 2) морфология, 3)генезис. На земной поверхности такая территория может быть отнесена к геоморфоблоку.

Под «морфологическим пейзажем» понимается вид рельефа, доступный субъекту путем чувственного восприятия и обладающий эстетическими свойствами привлекательности, в основе которых лежат объективные природные геоморфологические свойства. Оценку чувственного восприятия производят из соображений, что эстетическое впечатление от конкретного ландшафта зависит прежде всего от того, насколько полно в нем представлены все основные компоненты ландшафта - растительность, рельеф и водные поверхности. Территория может быть разбита на несколько классов оценки [3]:

Класс A - сочетание трех основных ландшафтных факторов - выразительность рельефа, живописных лесов и водоемов (водотоков);

Класс Б - сочетание двух основных ландшафтных факторов - рельефа и лесов, рельефа и водоемов, водоемов и лесов;

Класс В - наличие одного ландшафтного фактора - выразительного рельефа, леса или водоема (водотока);

Класс Г - прочие территории.

В результате опытной работы была составлена «Карта эстетической привлекательности рельефа» Саратова. Легенда к карте состоит из двух частей: I - морфологические ландшафты и II - морфологические пейзажи, выделенные по сочетанию ландшафтных факторов.

В Саратове и его окрестностях выделяются 7 морфологических ландшафтов, территориально совпадающих с размещением выделенных геоморфоблоков [4]:

1. Елшано-Курдюмская равнина;

2. Пристанско-Гусельская равнина;

3. Соколовогорский массив; 
4. Лысогорское плато;

5. Приволжская котловина;

6. Увекский массив;

7. Волгоградское водохранилище.

Анализ природных ситуаций показал, что выразительность рельефа постепенно усиливается вместе с увеличением его мезоформ и крутизны склонов. По карте углов наклона Саратова видно, что участки с уклонами более $10^{\circ}$ занимают около

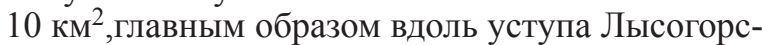
кого плато, а также в районах Соколовогорского и Увекского массивов. На карте показаны границы морфологических ландшафтов, которые являются переходными зонами с выраженным краевым эффектом - увеличением разнообразия, частыми перегибами рельефа, изменением полноты древостоя (открытые, полуоткрытые, закрытые лесные пейзажи), ярусностью древостоя, разницей высотных отметок. Таким образом, можно выделить три основных участка выразительного рельефа, кольцом окружающего центральную часть города. Природными доминантами в урбанизированном окружении Саратова являются Лысогорское плато, Соколовая гора и гора Увек.

В пределах морфологических ландшафтов были выделены следующие типы морфологических пейзажей:

Класс А - склоновые залесенные ущелья уступа Лысогорского плато, склоново-прибрежные залесенные ущелья Волгоградского водохранилища, водораздельные парковые ландшафты Соколовогорского массива, парковые ландшафты Городского парка культуры и отдыха, острова Волгоградского водохранилища;

Класс В - водораздельные открытые пространства с наличием панорамных точек, склоновые залесенные пространства и склоновые открытые пространства с наличием панорамных точек Лысогорского плато и Увекского массива, залесенная речная долина;

Класс C - водораздельные лесные территории Лысогорского плато, парковые ландшафты Приволжской котловины;

Класс Г - прочие территории (урбанизированные городские территории, садовые и дачные участки).

Рельеф Саратова и окрестностей представляется очень интересным и живописным. Максимальная расчлененность в пределах склонов Лысогорского плато составляет порядка 150-200 м, в пределах склонов Соколовогорского массива и горы Увек - порядка 100 м. Такая расчлененность рельефа характеризует контрастность территории, определяет высотное разнообразие природных комплексов, создает пейзажные панорамы и подчеркивает динамичность образа городских пейзажей в целом.

Соколовая гора и Увекский массив, являясь районами с выразительным рельефом благодаря своему геологическому строению, потеряли часть своих эстетических свойств из-за наличия нефтедобывающих и нефтеперерабатывающих производств.

При строительстве современного Саратова на современном месте были учтены эстетические цели - Приволжская котловина являлась красивейшим местом, окруженным со всех сторон холмами и величественной рекой Волгой. «В обрамлении красивых гор лежит город в живописной местности...» - так охарактеризовал Саратов один из иностранных путешественников, проезжавших по Волге в начале XIX века.

Залесенные территории с водоемами и живописным рельефом отводятся, как правило, для организации парков и зон отдыха. Пример создания парка - Городской парк им. Горького.

Смотровые площадки во многих городах благодаря природно-эстетическим функциям превращаются в доходные места. Со склонов Лысогорского плато и Соколовой горы открывается прекрасная панорама окрестностей Саратова. Самые доступные смотровые площадки на Соколовой горе, где установлен памятник «Журавли». Площадки хорошо оборудованы и служат естественным дополнением всему парковому комплексу. Набирает популярность смотровая площадка на Кумысной поляне при въезде в лесопарк. Летом 2005 г. там действовало кафе и хочется надеяться, что приход цивилизации только украсит это место, а не превратит в мусорку.

В Саратове есть примеры, когда естественные природные ландшафты удачно вписываются в план городской застройки и их природно-эстетические функции используются по назначению - создание парка Победы на Соколовой горе, Городского парка культуры и отдыха на месте запруженных Кладбищенского и Дегтярного оврагов, лесопарка «Кумысная поляна» на Лысогорском плато.

Один из комплексов социальных требований, которым должен отвечать город - это привлекательность или оригинальность местности. Эстетическая привлекательность во многом зависит от базисного элемента природного комплекса - рельефа. За основу эстетической оценки рельефа принимают известные всем понятия - «красота», «гармония», «привлекательность», возбуждающие в человеке положительные эмоции, а следовательно, физическую потребность в общении с отдельными категориями рельефа, творческую активность, выраженную в поэзии, живописи, скульптуре и т.д.

В теории ландшафтной планировки городских пространств производится оценка территории для дальнейших рекомендаций по ее использованию. Территории с уникальными ландшафтными объектами должны сохраняться как таковые. Застройка должна обходить их (минимальный отступ 0,5-1 км), здесь организуются зоны строгой охраны ландшафта заповедного типа. 


\section{Библиографический список}

1. Калашникова О.В. Методические основы оценки эстетичности ландшафтов // Вопросы дальневосточной географии. Владивосток, 2002.

2. Бредихин А.В. Рекреационная геоморфология - новое направление прикладных геоморфологических иссле-

УДК 551.4.011(470.44)

\section{ОПАСНЫЕ ПРОЦЕССЫ СОВРЕМЕННОГО ГЕОМОРФОГЕНЕЗА В САРАТОВСКОМ ПОВОЛЖЬЕ}

\section{Г.И. Лотоцкий, В.Н. Зайонц ${ }^{1}$}

Саратовский государственный университет, кафедра геоморфологии и геоэкологии E-mail: gis@sgu.ru

${ }^{1}$ кафедра общей геологии и полезных ископаемых

E-mail: decanat@geol.sgu.ru

Рассмотрены наиболее опасные процессы современного геоморфогенеза территории Саратовского Поволжья: линейный размыв, плоскостной смыв, дефляция, оползание и переформирование берегов Волгоградского и Саратовского водохранилищ.

Dangerous Processes of Modern Geomorphogenesis in Saratov Volga Region

\section{G.I. Lototsky, V.N. Zajonts}

The more dangerous processes of modern geomorphogenesis of the territory of Saratov Volga region have been considered: linear erosion, plane wash-away, deflusion, landslide and reforming of Volgograd and Saratov coast reservoirs.

Современный геоморфогенез представляет собой сложный процесс одновременного образования экзогенных форм рельефа и рыхлых отложений. Основными факторами данного процесса, кроме тектонических движений, являются характер рельефа, литология пород, особенности климата, почвенно-растительный покров и хозяйственная деятельность человека. Влияние последней заметно возросло во второй половине прошлого века, что привело к резкому увеличению интенсивности некоторых видов современного геоморфогенеза, получивших опасный характер на территории Саратовского Поволжья. Изучение данного процесса способствует пониманию сущности рельефообразования и образования рыхлых отложений, а также прогнозированию их развития и разработке мер защиты от их негативного воздействия.

Нерациональная обработка и использование почв склоновых поверхностей, а также такие факторы, как характер рельефа, климат, особенности геологического строения и почвенно-раститель- дований // Рельеф и человек: Материалы Иркутского геоморфологического семинара. Иркутск, 2004.

3. Вергунов А.П. Архитектурно- ландшафтная организация крупного города. Л., 1982.

4. Никифоров А.Н., Худяков Г.И. Концепция геоморфоблокового строения территории города Саратова // Географические исследования в Саратовском университете. Саратов, 2002.

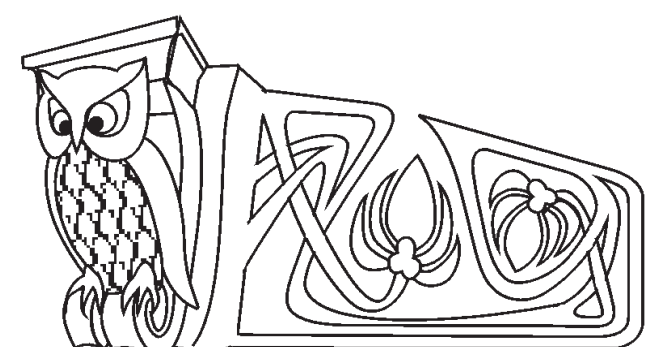

ные условия, привели к усилению так называемой «ускоренной» эрозии. Стационарные наблюдения, сравнительный анализ аэрофотоматериалов разных лет съемки, топографических карт, изданных в разные годы, позволили установить, что вершины многих оврагов растут со скоростью, исчисляемой метрами в год, а экстремальные значения достигают 10-15 м/год. Такие скорости зафиксированы нами в пределах Саратовского Правобережья в местах широкого распространения делювиальных суглинков легкого механического состава. Здесь на отдельных участках суммарная длина оврагов, приходящаяся на единицу площади, достигает 2,5 - 4,5 км/км² (Красноармейский, Вольский, Хвалынский, Базарно-Карабулакский и др. районы). Интенсивное овражное расчленение наблюдается в районе сел Сосновка - 1,5 км/км², Мордово - 1,7 км/км², Ахмат - 1,5 км/км², Трубино - 1,4 км/км², Нижняя Банновка - 1,8 км/км ${ }^{2}$. В этих же пунктах плотность оврагов достигает максимальных значений - от 2,5 до 4,5-5,5 единиц/км². Высокий коэффициент овражности отмечается в окрестностях Вольска $-2,4$ км/км ${ }^{2}$, у сел Воскресенска - 1,6 км/км², Казанлы - 1,4 км/км², Пугачева - 1,9 км/км², в бассейнах рp. Терешки, Чардыма, Курдюма, Хопра близ г. Балашова, в верховьях рр. Большой и Малый Аркадак и р. Терсы. Из антропогенных овражных форм наиболее активно развиваются придорожные и приплотинные. Основная часть прироста оврагов связана с периодами весенне-летних ливневых осадков и весеннего снеготаяния [1].

Одновременно катастрофически увеличилась скорость и интенсивность плоскостного смыва, наносящего огромный ущерб народному хозяйству. По данным различных источников и нашим полевым наблюдениям, в Саратовской области средне- и сильносмытые почвы занимают около 25\% пахотных угодий. В Балтайском и БазарноКарабулакском районах площади смытых земель занимают 20-30\% территорий, а в таких районах, 